\title{
MENELISIK FILM INDONESIA MELALUI PENDEKATAN KRISIS MULTI DIMENSI SERTA PARADOKS LINTAS HISTORIS
}

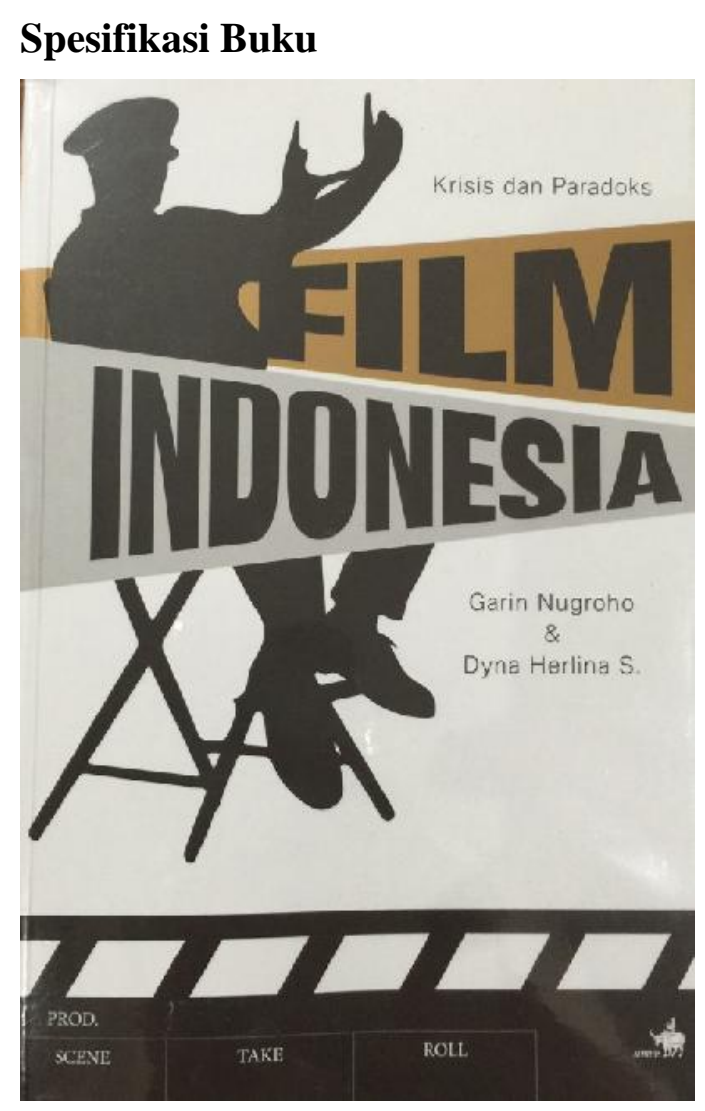

\begin{tabular}{|c|c|}
\hline \multicolumn{2}{|l|}{ Versi Nasional } \\
\hline Judul & $\begin{array}{l}\text { : Krisis dan Paradoks } \\
\text { Film Indonesia }\end{array}$ \\
\hline Pengarang & $\begin{array}{c}\text { : Garin Nugroho dan } \\
\text { Dyna Herlina } S .\end{array}$ \\
\hline Penerbit & : PT. Kompas Media \\
\hline
\end{tabular}
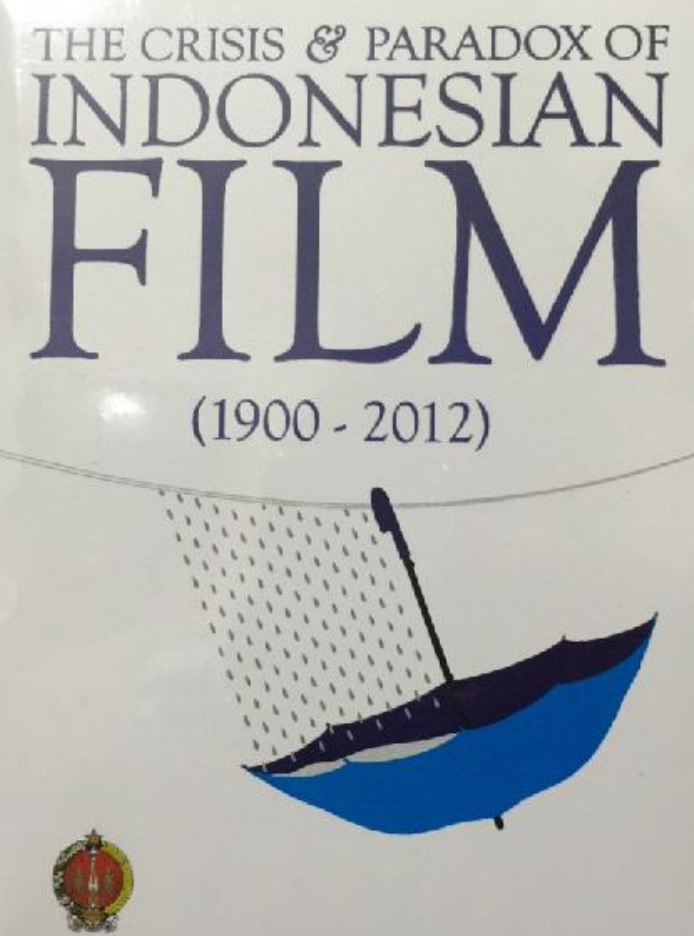

\section{International Version}

\begin{tabular}{|c|c|}
\hline Book title & $\begin{array}{l}\text { The Crisis and } \\
\text { Paradox of } \\
\text { Indonesian Film } \\
\text { (1900-2012) }\end{array}$ \\
\hline Authors & $\begin{array}{l}\text { Garin Nugroho and } \\
\text { Dyna Herlina S. }\end{array}$ \\
\hline Publisher & $\begin{array}{l}\text { Provincial Office for } \\
\text { Culture of } \\
\text { Yogyakarta } \\
\text { Province(Dinas } \\
\text { Kebudayaan Daerah } \\
\text { Istimewa } \\
\text { Yogyakarta) }\end{array}$ \\
\hline Publication Year & $: 2015$ \\
\hline $\begin{array}{l}\text { Edition } \\
\text { Number of pages }\end{array}$ & \\
\hline
\end{tabular}

Nusantara

Cetakan : 1

Tebal buku : 352 Halaman

Harga buku : Rp.67.000,- $\begin{array}{ll}\text { Edition } & : 1 \\ \text { Number of pages } & : 410 \text { pages }\end{array}$ 



\section{Dari Seni Pertunjukan ke Sinema}

Kompleksitas rekam jejak seni pertunjukan hingga wujud hiburan layar lebar di Nusantara menjadi domain perhatian penulis sepanjang penyusunan buku ini. Tak heran bila semenjak awal penulis tidak langsung menyinggung mengenai film sebagai produk budaya masyarakat, terlebih pada budaya lokal yang telah tumbuh berkembang secara tradisional. Mulai dari wayang, komedie stanboel, ludruk, ketoprak, hingga ke gambar idoep yang merepresentasikan kekhawatiran budaya. Berbagai aspek perkembangan seni pertunjukan tersebut menjadi pijakan berpikir dalam memposisikan ranah hiburan pada suatu paradoks industri hiburan, khususnya film Indonesia. Perspektif yang ditawarkan penulis meliputi cara pandang kekuasaan dan kepentingan bisnis serta relevansinya terhadap industri film di kotakota besar di Indonesia pada masa sebelum tahun 1930.

Sejarah film berikutnya dilatar belakangi kondisi depresi ekonomi dengan beranjak pada paradoks yang berbeda dari periode sebelumnya, dimana hiburan menjadi katarsis di kala masyarakat dilanda krisis. Kondisi dilematis terjadi ketika problematika antar bangsa melanda, di beberapa Negara terjadi ketimpangan jumlah serapan tenaga kerja, terbukanya peluang usaha atau pembukaan lapangan kerja di bidang industri perfilman di Tanah Air oleh beberapa tokoh, hingga munculnya film nasionalisme di era kemerdekaan Republik Indonesia. Paradoks tersebut berkembang ke ranah politik, seiring bertumbuhnya nasionalisme serta perseteruan ideologi yang tertuang dalam karya film Indonesia hingga awal era Orde Baru.

Pada masa setelah tahun 1970, para pelaku seni pertunjukan seakan-akan memberi reaksi berupa kekecewaan terhadap rezim Orde Baru. Bukan hanya nuansa politik, represi militer, nepotisme hingga monopoli bisnis "keluarga cendana" tak luput dari sorotan. Tokohtokoh yang terjun di dunia seni perfilman juga diberikan porsi cukup berimbang ketika menanggapi situasi tersebut. Penulis menandainya sebagai suatu paradoks stabilitas politik. Di sisi lain, situasi ini terdistraksi oleh kondisi perkembangan teknologi informasi yang sedemikian pesat hingga munculnya satelit. Konsekuensi yang terjadi, media televise secara tidak langsung mendorong budaya populer merebak di Indonesia. Tentu saja hal tersebut mempengaruhi selera khalayak penonton domestik, kemudian kontennya diwarnai oleh adaptasi komik serta peranan musik terhadap modernisasi industri penyiaran. Ulasan tidak berhenti sampai di situ saja, penulis mendeskripsikan pula geliat film nasional. Represi hingga prestasi film nasional, mulai dari dewan film, organisasi pekerjanya, badan sensor, kebijakan impor film, sutradara yang berkiprah di era tersebut, hingga sekolah produksi film. 
Globalisasi tidak berjalan mulus sebagaimana diutarakan sebelumnya, gejolak politik menjadi agenda utama yang mencuat sebagai paradoks di kala itu. Film nasional tumbuh dalam kondisi suasana kekecewaan rakyat terhadap pemerintahan di kala itu mulai memuncak hingga krisis multidimensi. Kondisi ini melahirkan dua (2) kelompok sineas nasional, yakni bertujuan untuk usaha pelestarian serta perlawanan. Pekerja seni kelompok yang pertama berupaya menumbuh kembangkan budaya sembari kemauan menyesuaikan produk dengan represi pemerintah, sementara kelompok kedua cenderung melakukan usaha konfrontasi dengan penguasa. Implikasi nyata dari kondisi ini terlihat langsung dari munculnya aneka genre film kala itu yang berusaha "melawan" krisis. Selanjutnya paradoks perfilman nasional memasuki babak baru, yakni munculnya sineas generasi sekolah film. Banyak ide baru yang disajikan ke layar kaca, pemahaman yang matang mengenai cara mengemas suatu gagasan ke dalam produk sinema di benak penonton. Generasi sekolah film menyiratkan perubahan yang cukup signifikan, dari aliran artistik seperti Teguh Karya hingga generasi otodidak yang diwakili Wim Umboh.

Situasi berganti, rezim pemerintahan beranjak ke euforia demokrasi. Kondisi ini pun menjadi pijakan sineas berkarya, dimana konflik suku dan agama merebak di berbagai pulau serta munculnya gesekan-gesekan sosial dalam masyarakat. Paradoks demokrasi yang penuh kekerasan, diwarnai situasi jenuh politik dan radikalisme menanggapi sepuluh tahun reformasi. Hal ini diperparah oleh usaha percepatan sosial politik secara fundamental oleh pemerintahan transisi menyisakan peristiwa bom dan kerusuhan di beberapa tempat hingga lepasnya salah satu provinsi di Indonesia. Kondisi yang kontradiktif dengan film-film nasional yang ketika itu mulai bangkit serta memberikan kontribusi prestasi di kancah internasional. Selain Riri Riza yang konsisten berkarya, nama-nama yang mulai bermunculan ketika itu mulai dari Edwin, Teddy Soeriaatmadja, Mouly Surya, Ifa Isfansyah, Dirmawan Hatta, Kamila Andini, dan Yosep Anggi Noen. Selanjutnya, liberalisasi ekonomi nasional turut memberi kontribusi dalam perkembangan film nasional. Pertumbuhan sosial ekonomi mendorong tumbuhnya pasar baru yang mengelola kebutuhan simbolik beragama, dalam wujud jilbab atau sering disebut juga hijab. Sembari industri tersebut berjalan, budaya populer kian menjamur hingga merebak kepada tema-tema baru yang sebelumnya jarang “disentuh" film nasional, seperti tema-tema religi yang menayangkan muslim dalam nilainilai baru serta Lesbian, Gay, Biseksual, dan Transgender (LGBT). Paradoks ini menempatkan film nasional dalam wacana agama dan keterbukaan hidup.

\section{Identifikasi Paradoks Film Nasional}


Berdasarkan pembahasan buku ini memperlihatkan bahwa produksi film nasional tidak dapat lepas dari konteks sosial, politik, ekonomi, agama, dan budaya. Meski tidak dapat ditarik kesimpulan secara eksplisit serta dilerai berdasarkan kategorikal, namun penulis secara tegas ingin menegaskan sejarah pergolakan Bangsa Indonesia tidak luput dari usaha menggairahkan seni pertunjukan sebagai wujud paradoks ekspresi budaya. Sebaliknya, film nasional lahir dan berkembang dengan berbagai lika-likunya muncul sebagai refleksi krisis serta paradoks yang menyertai.

Bila dicermati secara mendalam dengan mengacu pada perspektif film nasional, penulis ingin memperlihatkan bahwa paradoks yang menyertai krisis perfilman didasari atas dua aspek besar, yakni sisi internal dan eksternal. Sisi internal lebih ditujukan pada perkembangan film nasional dari produksi hingga perjalanan sejarahnya, sementara sisi ekstenal lebih kepada konteks yang berkembang di lingkungan masyarakat secara nasional. Melihat lingkup terluar, maka sisi eksternal film nasional sebagai implikasi atas paradoks berkembangnya situasi politik pra hingga pasca kemerdekaan Republik Indonesia, kemudian berkembang menjadi paradoks stabilitas politik di era Orde Baru, lalu paradoks gejolak politik melihat kekecewaan masyarakat pada kebijakan pemerintah, di tengah perjalanan muncul paradoks percepatan sosial politik pemerintahan transisi, hingga berakhir pada paradoks pergeseran ajaran agama muslim dan menyeruaknya keterbukaan identitas budaya masyarakat.

Di sisi internal, kehadiran film nasional diawali paradoks industri hiburan seni pertunjukkan, dilanjutkan dengan paradoks geliat film nasional. Sedari krisis yang menyelimuti selama beberapa waktu hingga kebangkitannya. Berlanjut pada paradoks sineas generasi sekolah film yang ditandai dengan prestasi sineas muda di kancah internasional, diakhiri dengan pembahasan paradoks ini menempatkan film nasional dalam wacana agama dan keterbukaan hidup.

\section{Perbaikan Fundamental}

Materi yang tersaji dalam buku ini dapat diberi pujian, mengingat tidak banyak atau bahkan tergolong langka untuk diperoleh suatu kajian multi dimensi yang membahas mengenai dunia perfilman di Tanah Air. Di sisi lain, guna perbaikan kualitas penerbitan ke depan perlu dicermati dua hal, yakni revisi secara substansial dan redaksional. Perbaikan substansial ditinjau dari perspektif penulis dalam tulisan serta pola penjabaran paradoks yang dituangkan dalam beberapa pembabakan, sementara bila ditinjau dari aspek redaksional sebaiknya memperhatikan alur pembahasan dan penulisan tahun sebagai dimensi historisitas yang sangat fundamental. 
Di dalam buku ini terdapat pengalaman pribadi atau personal opinion dari penulis, baik selaku sutradara maupun pelaku sejarah film dari berbagai dekade waktu. Tentu saja nama Garin Nugroho terdengar cukup familiar di kalangan penikmat film lintas generasi, namun adanya keterbatasan manusia perlu diakui sehingga perlu adanya usaha untuk menghadirkan second opinion yang memperkuat data dari berbagai perspektif. Kalaupun opini pribadi tidak direduksi, ada baiknya diklarifikasi dengan pendapat para ahli di bidang yang sama dari perspektif berbeda. Dapat pula menghadirkan pendapat sineas dari generasi muda yang sempat disinggung dalam buku.

Terdapat beberapa bagian bahasan yang menarik dan jarang ditemukan pada buku sejenis, namun justru konteks bahasan yang sedemikian luas acapkali tidak mengacu kepada judul utama yang diusung oleh buku ini. Paradoks yang melekat pada konteks sosial sebaiknya diungkapkan secara eksplisit agar mudah dipahami khalayak pembaca.

Alur pembahasan perfilman yang dikupas secara rinci, holistik, dan kompleks ini dapat menjadi boomerang tersendiri. Pembaca kalangan muda yang lebih membutuhkan informasi tersebut dapat mudah merasa bosan, maka ada baiknya penulis menawarkan hal-hal yang lebih "membumi" dari aspek teknis alur film yang lebih digemari pembaca. Hal ini menjadi penting karena aspek sejarah menjadi domain utama proses pembelajaran generasi penerus bangsa.

Penanda jaman yang ditunjukan oleh pembabakan bab dalam buku yang perlu diklarikasi terletak pada pencatuman tahun, yakni 1930-1950, 1950-1970, 1970-1985, 19851998, dan 1998-2013. Pada setiap periode, tentunya tidak berpijak pada tahun yang sama. Sebagai contoh tahun 1950, 1970, 1985, dan 1998 tercantum pada tiap periode, akan lebih bijak dan tidak membingungkan pembaca bila dicantumkan sebagai berikut: 1930-1950, 1951-1970, 1971-1985, 1986-1998, dan 1999-2013.

\section{Simpulan dan Rekomendasi}

Buku ini menunjukkan bahwa dampak budaya global dalam perkembangan seni pertunjukan menjadi penanda sejarah perfilman di Indonesia. Tidak hanya itu saja, di dalam buku ini pula terdapat beberapa permasalahan politik, sosial, ekonomi, ideologi kemerdekaan, kebebasan, pembasmian komunis dan radikalisme.

Banyak pengetahuan baru yang bermanfaat dibahas, terutama dibagi dalam tahapantahapan, salah satunya berupa upaya melawan arus globalisasi yang menerpa. Dewasa ini terpaan media berwujud tayangan film asing cenderung menjadi anomali perfilman nasional yang berusaha menumbuhkan kecintaan terhadap film nasional. Terlepas dari kondisi masyarakat di jaman sekarang yang cenderung menikmati produk film tanpa ingin 
mengetahui lebih dalam aspek sejarahnya, buku ini menawarkan paradoks yang didasarkan atas konteks sosial poltik dalam hidup bernegara dan bermasyarakat.

Target pembaca tidak hanya terpaku pada disiplin ilmu komunikasi, melainkan dari ilmu sejarah, ekonomi, politik, sosial, budaya, kajian film, desain komunikasi visual. Bila ditinjau dari perspektif ilmu komunikasi, maka berbagai peminatan terkait periklanan (advertising), penyiaran (broadcasting) dapat memetik banyak hal dari buku ini. Demikian pula para pengajar multimedia di bangku sekolah menengah kejuruan hingga pengajar bidang kekhususan yang telah diungkapkan di atas pada tingkat perguruan tinggi.

Praktisi serta pelaku industri film diharapkan mampu memetik pembelajaran berharga atas rekam jejak sinema nasional. 